\title{
Wojciech Polan*
}

Uniwersytet Ekonomiczny w Krakowie

\section{ANALIZA ZMIAN PODOBIEŃSTWA STRUKTUR HANDLU ZAGRANICZNEGO NOWYCH KRAJÓW CZŁONKOWSKICH UNII EUROPEJSKIEJ W LATACH 2004-2015 - W KIERUNKU DALSZEJ KONWERGENCJI NA JEDNOLITYM RYNKU**}

\begin{abstract}
Streszczenie
W artykule podjęto próbę wyjaśnienia, czy postępujące w kolejnych latach po akcesji zmiany w strukturze wymiany towarowej krajów UE-10 wskazują na realizację procesu konwergencji na jednolitym rynku europejskim. Innymi słowy, czy w świetle rozszerzenia Unii Europejskiej w 2004 oraz 2007 roku, rynki krajów UE-10 i UE-15 traktowane są przez importerów i eksporterów zarówno z krajów UE-15 i UE-10 w coraz większym zakresie jako jednolity rynek. Wyniki analizy potwierdzają tendencje zbliżania się struktur wymiany handlowej Nowych Państw Członkowskich (UE-10) w ich wymianie wzajemnej do analogicznych struktur z krajami UE-15. Szczególnie importerzy krajów UE-10 i UE-15 przyczyniają się do upodabniania struktur wymiany. Utrwalają oni strategiczne relacje handlowe, które - względem państw trzecich - budują obraz jednolitego rynku europejskiego.

Słowa kluczowe: konwergencja, jednolity rynek europejski, handel zagraniczny

* Adres e-mail: wpolan@gmail.com.

** Publikacja jest wynikiem badan dofinansowanych ze środków Narodowego Centrum Nauki przyznanych na podstawie decyzji nr 2015/17/N/HS4/01529.
\end{abstract}




\section{Wprowadzenie}

Zmiany geograficznej i towarowej struktury eksportu i importu państw są jednym z istotnych skutków procesu transformacji gospodarczej. Potwierdziły to m.in. analizy przeprowadzone dla krajów założycielskich CEFTA (por. Czubek, Molendowski, 2005; Kopeć, 1995; Molendowski, 2003) oraz badania dla nowych krajów członkowskich UE porównujące tendencje dla pierwszych lat przed i po akcesji (Molendowski, 2007; Polan, 2010; Molendowski, Polan 2013). Regionalna liberalizacja handlu okazała się jednym z najważniejszych czynników wpływających na zmiany w strukturze ich eksportu i importu.

Uczestnictwo w jednolitym rynku europejskim (JRE) ma m.in. na celu konwergencję gospodarek krajów członkowskich oraz dynamizację mechanizmów dobrobytowych. Celem jest wyrównanie luki rozwojowej nowych krajów członkowskich poprzez najlepsze wykorzystanie ich potencjału w ramach mechanizmów tej wysokiej fazy integracji. Zasadnym więc pozostaje pytanie, czy postępujące w kolejnych latach po akcesji zmiany w strukturze wymiany towarowej krajów UE-10 wskazują na realizację procesu konwergencji.

Dopełnieniem dotychczasowych publikacji na ten temat może być prezentacja wyników analizy przekształceń w strukturze towarowej handlu zagranicznego nowych krajów członkowskich (UE-10) na tle krajów UE-15 w ich handlu wzajemnym oraz z państwami UE-15 w latach 2004-2015.

\section{Podstawowe tendencje ekonomiczno-handlowe w krajach UE-10 po akcesji}

Analiza podstawowych tendencji ekonomiczno-handlowych wykazała, że nowe kraje członkowskie Unii Europejskiej są gospodarkami otwartymi, w których ważną rolę pobudzającą wzrost odgrywa handel zagraniczny. Statystyki rachunków narodowych - m.in. znacznie większa dynamika eksportu niż popytu wewnętrznego - potwierdziły, że aktywny rozwój wymiany handlowej w tych państwach w okresie po akcesji był jednym z istotnych czynników odpowiedzialnych za utrzymywanie się wysokiej dynamiki PKB (zob. Polan, 2015). Obroty handlowe krajów UE-10 rosły w okresie 2004-2015 znacznie szybciej niż w krajach piętnastki (por. rys. 1) - prawie 2,5-krotny wzrost eksportu i importu, podczas gdy w UE-15 tylko 
1,5 razy. PKB „piętnastki” osiągnął w tym czasie dynamikę na poziomie poniżej 130\%, gdy gospodarki krajów UE-10 rozwinęły się prawie dwukrotnie (z poziomu 570 mld euro do ponad 1,1 bln euro). Z tych względów, wskaźnik otwartości gospodarek nowych państw członkowskich w roku 2015 był nadal dwukrotnie wyższy niż w państwach UE-15.

Rysunek 1. Wskaźniki otwartości gospodarek ([EX + IM] / PKB) UE-10 i UE-15 w latach 2004-2015 (\%)

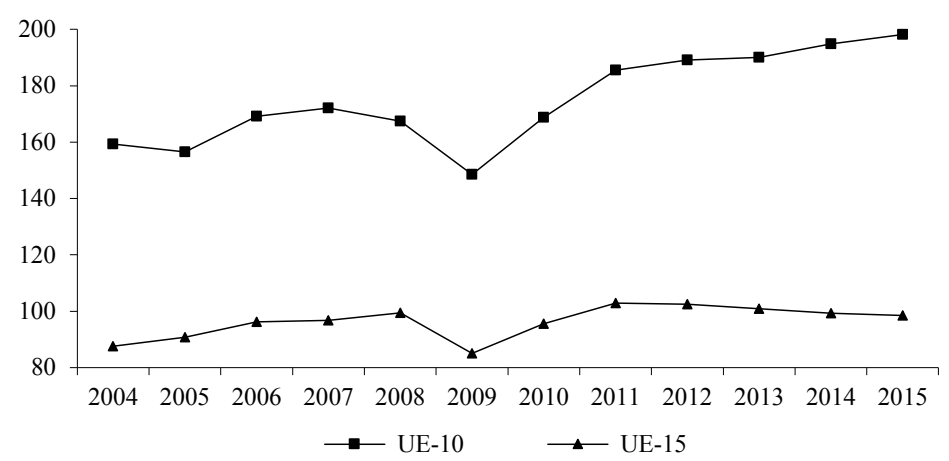

\begin{tabular}{|c|c|c|c|c|c|c|c|c|c|c|c|c|c|}
\hline $\begin{array}{l}\text { Rok/ } \\
\text { grupa }\end{array}$ & 2004 & 2005 & 2006 & 2007 & 2008 & 2009 & 2010 & 2011 & 2012 & 2013 & 2014 & 2015 & \begin{tabular}{|c|} 
Dynamika \\
$2015 / 2004$ \\
$(\%)$
\end{tabular} \\
\hline \multicolumn{14}{|c|}{ Eksport + Import (mld EUR) } \\
\hline UE-10 & 908 & 1041 & 1264 & 1499 & 1660 & 1302 & 1597 & 1847 & 1905 & 1952 & 2064 & 2202 & 242 \\
\hline UE-15 & 9169 & 9865 & 11007 & 11652 & 11914 & 9650 & 11269 & 12480 & 12679 & 12571 & 12787 & 13320 & 145 \\
\hline \multicolumn{14}{|c|}{ PKB (mld EUR) } \\
\hline UE-10 & 570 & 665 & 747 & 871 & 992 & 877 & 946 & 995 & 1007 & 1027 & 1059 & 1111 & 195 \\
\hline UE-15 & 10476 & 10869 & 11446 & 12045 & 11989 & 11350 & 11801 & 12126 & 12371 & 12462 & 12875 & 13532 & 129 \\
\hline \multicolumn{14}{|c|}{ Wskaźnik otwartości gospodarki (EX + IM)/PKB (\%) } \\
\hline UE-10 & 159 & 157 & 169 & 172 & 167 & 149 & 169 & 186 & 189 & 190 & 195 & 198 & 124 \\
\hline UE-15 & 88 & 91 & 96 & 97 & 99 & 85 & 95 & 103 & 102 & 101 & 99 & 98 & 112 \\
\hline
\end{tabular}

Źródło: Eurostat. EasyComext; obliczenia własne.

Zmiana warunków handlu będąca wynikiem akcesji państw UE-10 do Unii Europejskiej przyczyniła się do istotnego zwiększenia dynamiki wzajemnych powiązań handlowych. Badanie dynamiki obrotów zagranicznych obu grup państw (UE-10 i UE-15) potwierdziło, że obszar nowych krajów członkowskich stał się znaczącym rynkiem sprzedaży produkowanych w tych państwach towarów oraz 
zaspokajania popytu importowego ich konsumentów i zakładów przemysłowych. W latach 2004-2015 doszło bowiem do największego zdynamizowania obrotów w relacji z krajami UE-10 (por. rys. 2). Było to możliwe m.in. dzięki ujednoliceniu wzorów dotyczących rozwoju wymiany handlowej krajów UE-10 i UE-15, zharmonizowaniu preferencji konsumenckich oraz pogłębiających się form współpracy i zachodzących interakcji na szczeblu przedsiębiorstw. System gospodarczy krajów UE-10 i UE-15 zarówno z punktu widzenia firm, jak i konsumentów, podążał w kierunku jednolitego rynku.

Rysunek 2. Dynamika obrotów handlowych krajów UE-10 i UE-15 w latach 2004-2015

$(2004 \mathrm{r} .=100 \%)$

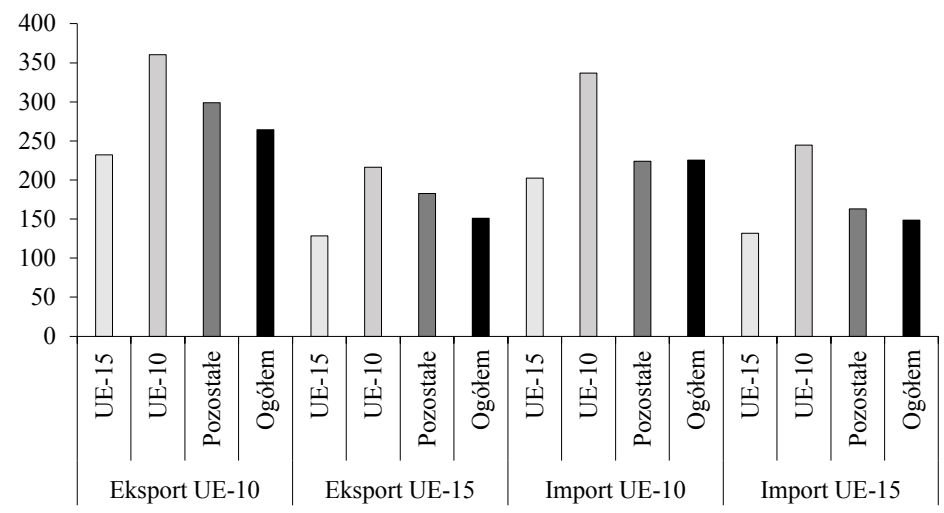

\begin{tabular}{|c|c|c|c|c|c|c|c|}
\hline \multirow[b]{2}{*}{ Partner } & \multirow[b]{2}{*}{ Grupa } & 2004 & 2015 & \multirow{2}{*}{$\begin{array}{c}\text { Dynamika } \\
2015 / 2004 \\
(\%)\end{array}$} & 2004 & 2015 & \multirow{2}{*}{$\begin{array}{c}\text { Dynamika } \\
2015 / 2004 \\
(\%)\end{array}$} \\
\hline & & \multicolumn{2}{|c|}{ Import (mld EUR) } & & \multicolumn{2}{|c|}{ Eksport (mld EUR) } & \\
\hline \multirow{2}{*}{ Ogółem } & UE-10 & 275,6 & 621,5 & 226 & 238,3 & 630,3 & 264 \\
\hline & UE-15 & 2740,7 & 4072,5 & 149 & 2784,5 & 4211,5 & 151 \\
\hline \multirow{2}{*}{ UE-15 } & UE-10 & 166,5 & 336,8 & 202 & 155,8 & 361,4 & 232 \\
\hline & UE-15 & 1637,3 & 2158,7 & 132 & 1710,3 & 2196,2 & 128 \\
\hline \multirow{2}{*}{ UE-10 } & UE-10 & 35,9 & 121,1 & 337 & 36,3 & 130,8 & 361 \\
\hline & UE-15 & 139,7 & 342,1 & 245 & 156,7 & 339,0 & 216 \\
\hline \multirow{2}{*}{ Kraje trzecie } & UE-10 & 73,1 & 163,7 & 224 & 46,2 & 138,1 & 299 \\
\hline & UE-15 & 963,7 & 1571,7 & 163 & 917,5 & 1676,2 & 183 \\
\hline
\end{tabular}

Źródło: Eurostat. EasyComext; obliczenia własne. 


\section{Zmiany podobieństwa struktur eksportu krajów UE-10 do krajów UE-15 oraz w handlu wzajemnym}

W latach 2004-2015 w krajach UE-10 wystąpił proces upodabniania struktur ich sprzedaży zagranicznej w wymianie wzajemnej do krajów ,piętnastki”. Średnia wartość wskaźnika odległości Euklidesa spadła bowiem z poziomu 0,160 w 2004 roku do $0,134 \mathrm{w}$ roku $2015^{1}$. Takiej tendencji sprzyjało upodabnianie badanych struktur eksportu aż w siedmiu państwach (z wyjątkiem Węgier, Estonii i Słowacji) (por. tab. 1, rys. 4). Porównanie wskaźników w okresie 2004-2008 oraz 2009-2015 wykazało jednocześnie, że zakłócenia wywołane przez światowy kryzys gospodarczy istotnie zahamowały ten proces - zakres podobieństwa analizowanych struktur eksportu został już osiągnięty w roku 2008 i kształtował się na tym samym poziomie w roku 2015. W badanym okresie, po kryzysie (2009-2015), aż w sześciu państwach wskaźniki odległości Euklidesa wzrosły (były to Węgry, Bułgaria, Litwa, Łotwa, Estonia i Słowacja).

${ }^{1}$ Mając na celu znalezienie odpowiedzi na określone pytania badawcze, w analizie skupiono się na określeniu odległości pomiędzy strukturami z wykorzystaniem wybranej miary podobieństwa. Zastosowano miernik „odległość Euklidesa”, główny miernik z grupy wskaźników opartych na absolutnych różnicach indywidualnych wskaźników struktury, według następującego wzoru:

gdzie:

$$
e_{j}=\left(\sum_{i=1}^{n}\left|\alpha_{i j}-\beta_{i j}\right|^{2}\right)^{\frac{1}{2}}
$$

$\alpha_{i j}$ - udział danej grupy towarowej (oznaczonej kodem CN-4) w eksporcie lub imporcie danego kraju do UE-15,

$\beta_{i j}-$ udział danej grupy towarowej (oznaczonej kodem CN-4) w eksporcie lub imporcie danego kraju do UE-10,

$i$ - grupy towarowe według pozycji taryfy celnej w dezagregacji 4-cyfrowej,

$n$ - liczba badanych grup towarowych (oznaczonych kodami CN-4),

$j$ - rok, z badanego przedziału 2004-2015.

Wskaźnik „odległości Euklidesa” mierzony powyższym wzorem przyjmuje wartości od 0 do 1 . Gdy przyjmuje on wartości zbliżone do 1, oznacza, że większy jest stopień zróżnicowania badanych struktur. Natomiast jeżeli wartość obliczonego wskaźnika zbliża się do 0, analizowane struktury są bardziej do siebie zbliżone. Szerzej por. Czubek, Molendowski (2005); Molendowski, Polan (2013). 


\section{Rysunek 3. Kraje poddane analizie struktur wymiany handlowej}

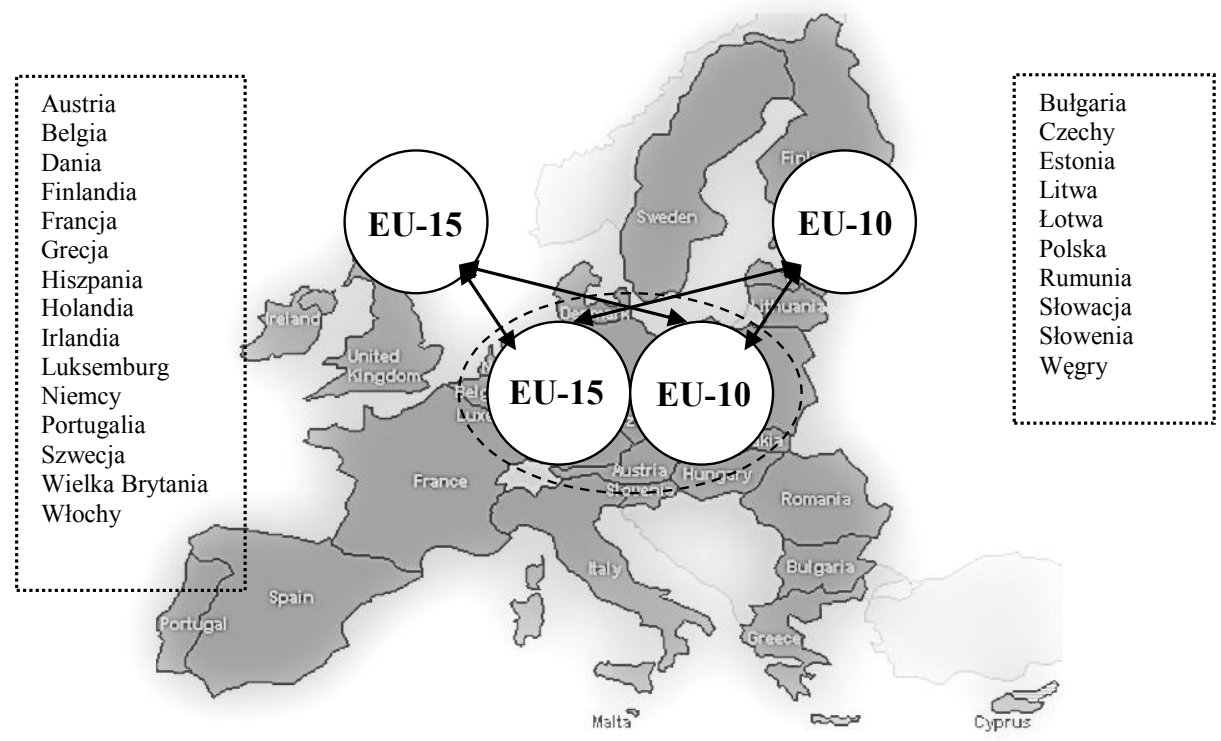

Źródło: opracowanie własne.

W analizowanym okresie po akcesji (2004-2015), w krajach UE-15 wystąpił proces różnicowania struktur ich eksportu do krajów UE-10 i w handlu wzajemnym. Średnia wartość wskaźnika odległości Euklidesa wzrosła z poziomu 0,105 w 2004 roku do 0,119 w 2015 roku. Jedynie w przypadku sześciu państw wskaźniki odległości Euklidesa obniżyły się (Włochy, Dania, Finlandia, Grecja, Portugalia, Holandia). W przypadku krajów UE-15, zmiany tendencji w tym zakresie miały silniejszy charakter niż w krajach UE-10. Dowodem jest to, że w latach 2004-2008 wartość średnia obliczonej miary podobieństwa spadła z 0,105 do 0,104, podczas gdy w latach po kryzysie (2009-2015) wartość ta wzrosła z 0,110 do 0,119.

Powyższe tendencje wskazują, iż w analizowanym okresie po akcesji nie wystąpił wyraźny proces konwergencji eksportowej na JRE, definiowanym w tym przypadku jako jednolity obszar gospodarczy 25 państw członkowskich (UE-10 i UE-15). Eksporterzy z krajów UE-10 zbudowali na tym obszarze bardziej trwałe, strategiczne relacje handlowe. Z kolei ich odpowiednicy z krajów UE-15 w okresie 
kryzysu traktowali obszar handlu wzajemnego jako bardziej stabilny, a rynek krajów UE-10 nadal jako taktyczny obszar, na którym można dokonywać bardziej elastycznych adaptacji różnicujących strukturę wymiany.

Tabela 1. Wskaźniki podobieństwa struktur eksportu (wg odległości Euklidesa) krajów UE10 i UE15

\begin{tabular}{|c|c|c|c|c|c|c|c|c|c|c|c|c|c|}
\hline & rai & 2004 & 2005 & 006 & 2007 & 2008 & 2009 & 2010 & 011 & 2012 & 2013 & 014 & 015 \\
\hline \multirow{11}{*}{ UE10 } & & 098 & 0,083 & 090 & 0,077 & 0,077 & 0,107 & 098 & 0,087 & 0,076 & 0,067 & 0,063 & 0,058 \\
\hline & Czechy & 0,092 & 0,084 & 0,082 &, 075 & 0,079 & 0,096 & 0,095 & 0,094 & 0,091 & 0,080 & 0,082 & 0,082 \\
\hline & Rumunia & 0,139 & 0,162 & 0,148 & 0,137 & 0,138 & 0,129 & 0,123 & 0,107 & 0,094 & 0,094 & 0,091 & 0,083 \\
\hline & Węgry & 0,103 & 0,086 & 0,084 & 0,075 & 0,075 & 0,096 & 0,097 & 0,106 & 0,093 & 0,100 & 0,112 & 0,112 \\
\hline & Bułgaria & 0,170 & 0,130 & 124 & 0,161 & 0,119 & 0,106 & 0,111 & 0,126 & 0,121 & 0,125 & 0,117 & 0,116 \\
\hline & Słowenia & 0,179 & 0,179 & 0,168 & 0,144 & 0,138 & 0,170 & 0,169 & 0,153 & 0,134 & 0,130 & 0,130 & 0,123 \\
\hline & Łotwa & 0,276 & 0,245 & 0,216 & 0,203 & 0,149 & 0,152 & 0,166 & 0,165 & 0,168 & 0,174 & 0,175 & 0,175 \\
\hline & Litwa & 0,203 & 0,167 & 0,151 & 0,185 & 0,094 & 0,170 & 0,118 & 0,129 & 0,161 & 0,172 & 0,152 & 0,176 \\
\hline & Estonia & 0,160 & 0,184 & 0,211 & 0,204 & 0,168 & 0,132 & 0,171 & 0,202 & 0,216 & 0,213 & 0,224 & 0,193 \\
\hline & Słowacja & 0,182 & 0,175 & 195 & 0,209 & 0,194 & 0,188 & 0,179 & 0,184 & 0,207 & 0,214 & 0,219 & 0,224 \\
\hline & Średnia* & & 0,149 & 147 & 0,147 & 0,123 & 0,135 & 0,133 & 0,135 & 0,136 & 0,137 & $\mathbf{0 , 1 3 7}$ & 0,134 \\
\hline \multirow{16}{*}{ UE15 } & Średnia* & 105 & 0,112 & 109 & 0,104 & 0,104 & 0,110 & 0,108 & 0,113 & 0,126 & 0,120 & 0,115 & 0,119 \\
\hline & Włochy & 0,057 & 0,056 & 0,053 & 0,046 & 0,043 & 0,050 & 0,046 & 0,047 & 0,054 & 0,057 & 0,062 & 0,055 \\
\hline & Belgia & 0,056 & 0,064 & 0,066 & 0,066 & 0,070 & 0,056 & 0,071 & 0,084 & 0,092 & 0,094 & 0,085 & 0,075 \\
\hline & Francja & 0,064 & 0,068 & 0,109 & 0,070 & 0,081 & 0,091 & 0,082 & 0,085 & 0,081 & 0,083 & 0,073 & 0,076 \\
\hline & Dania & 0,104 & 0,148 & 0,129 & 0,118 & 0,127 & 0,109 & 0,113 & 0,122 & 0,127 & 0,123 & 0,099 & 0,097 \\
\hline & \begin{tabular}{|l|} 
Niemcy \\
\end{tabular} & 0,094 & 0,092 & 0,083 & 0,085 & 0,074 & 0,083 & 0,082 & 0,087 & 0,087 & 0,087 & 0,091 & 0,100 \\
\hline & Finlandia & & 0,114 & 0,102 & 0,088 & 0,097 & 0,094 & 0,067 & 0,074 & 0,089 & 0,093 & 0,091 & 0,101 \\
\hline & Hiszpania & 0,081 & 0,091 & 0,091 & 0,082 & 0,062 & 0,113 & 0,092 & 0,118 & 0,119 & 0,114 & 0,101 & 0,101 \\
\hline & W1k. Bry & 0,093 & 0,096 & 0,143 & 0,092 & 0,114 & 0,102 & 0,114 & 0,106 & 0,154 & 0,143 & 0,132 & 0,104 \\
\hline & Grecja & 0,145 & 0,158 & 0,167 & 0,148 & 0,125 & 0,135 & 0,130 & 0,125 & 0,158 & 0,129 & 0,105 & 0,114 \\
\hline & Portugalia & 0,125 & 0,116 & 0,122 & 0,138 & 0,131 & 0,144 & 0,145 & 0,150 & 0,137 & 0,141 & 0,130 & 0,120 \\
\hline & Szwecja & 0,090 & 0,087 & 0,083 & 0,083 & 0,091 & 0,095 & 0,109 & 0,114 & 0,129 & 0,133 & 0,141 & 0,125 \\
\hline & Holandia & 0,128 & 0,146 & 0,138 & 0,123 & 0,121 & 0,114 & 0,133 & 0,148 & 0,156 & 0,143 & 0,144 & 0,126 \\
\hline & Austria & 0,079 & 0,108 & 0,084 & 0,075 & 0,085 & 0,080 & 0,086 & 0,088 & 0,124 & 0,145 & 0,138 & 0,139 \\
\hline & Irlandia & 0,203 & 0,183 & 0,185 & 0,212 & 0,216 & 0,225 & 0,216 & 0,166 & 0,193 & 0,184 & 0,189 & 0,205 \\
\hline & Luksemburg & 0,134 & 0,157 & 0,087 & 0,140 & 0,128 & 0,158 & 0,135 & 0,190 & 0,191 & 0,127 & 0,140 & 0,246 \\
\hline
\end{tabular}

* Średnia arytmetyczna wskaźników podobieństwa wszystkich krajów w danym roku.

Źródło: Eurostat. EasyComext; obliczenia własne. 
Rysunek 4. Wskaźniki podobieństwa struktur eksportu

(wg odległości Euklidesa) krajów UE10 i UE15

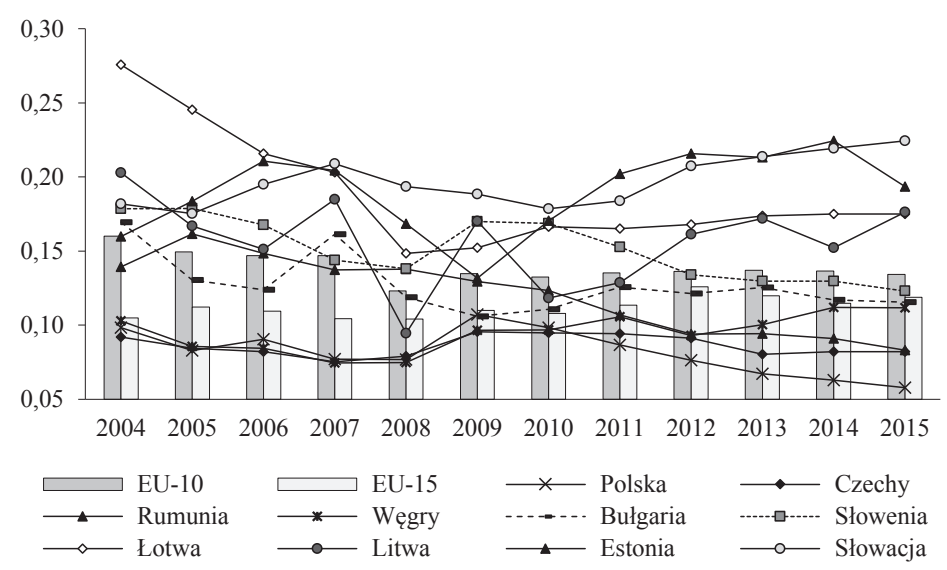

Zakresy minimalne i maksymalne oraz wartości średnie wskaźników odległości Euklidesa:

EU-10 Export

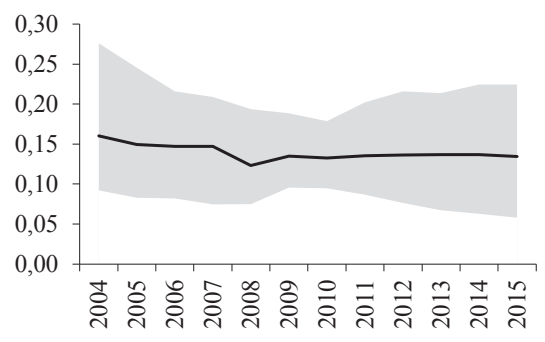

EU-15 Export

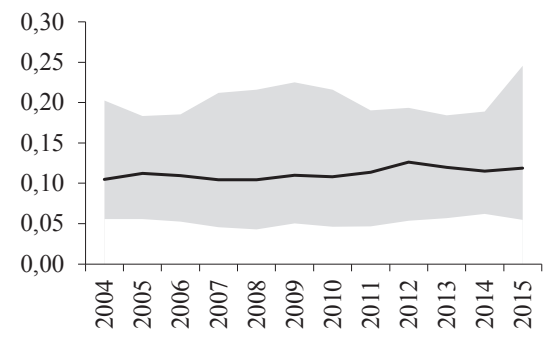

Źródło: na podstawie danych w tab. 1.

\section{Zmiany podobieństwa struktur importu krajów UE-10 z krajów UE-15 oraz w handlu wzajemnym}

Analiza struktury importu na JRE krajów (UE-10 i UE-15) wykazała, że latach 2004-2015 w obu grupach państw wystąpił proces upodabniania struktur ich sprzedaży zagranicznej do UE-10 oraz do krajów piętnastki. Średnia wartość wskaźnika odległości Euklidesa spadła z poziomu 0,112 w 2004 roku do 0,087 w roku 2015 dla państw UE-10. Dla państw UE-15 odpowiednią tendencję obrazują wartości 0,159 
(2004 r.) i 0,118 (2015 r.). Takiej tendencji sprzyjało upodabnianie badanych struktur eksportu w aż 21 państwach (z wyjątkiem Słowacji, Niemiec, Francji i Holandii) (por. tab. 2).

Tabela 2. Wskaźniki podobieństwa struktur importu

(wg odległości Euklidesa) krajów UE10 i UE15

\begin{tabular}{|c|c|c|c|c|c|c|c|c|c|c|c|c|c|}
\hline & Kraj & 004 & 2005 & 2006 & 2007 & 2008 & 2009 & 2010 & 2011 & 2012 & 2013 & 2014 & 2015 \\
\hline \multirow{11}{*}{ UE10 } & Rumunia & 090 & 0,089 & 0,081 & 0,079 & 0,077 & 0,068 & 0,072 & 0,073 & 0,073 & 0,066 & 0,064 & 0,063 \\
\hline & Polska & 0,096 & 0,100 & 0,081 & 0,072 & 0,072 & 0,081 & 0,078 & 0,079 & 0,077 & 0,081 & 0,073 & 0,067 \\
\hline & Czechy & 0,107 & 0,102 & 0,093 & 0,084 & 0,084 & 0,081 & 0,085 & 0,079 & 0,078 & 0,074 & 0,073 & 0,074 \\
\hline & Litwa & 0,080 & 0,076 & 0,086 & 0,086 & 0,085 & 0,078 & 0,091 & 0,089 & 0,096 & 0,077 & 0,084 & 0,076 \\
\hline & Łotwa & 0,147 & 0,140 & 0,127 & 0,125 & 0,158 & 0,129 & 0,094 & 0,127 & 0,132 & 0,117 & 0,078 & 0,082 \\
\hline & Słowenia & 092 & 0,093 & 0,081 & 0,092 & 0,082 & 0,088 & 0,075 & 0,071 & 0,071 & 0,064 & 0,078 & 0,084 \\
\hline & \begin{tabular}{|l|} 
Węgry \\
\end{tabular} &, 100 & 0,105 & 0,110 & 0,097 & 0,097 & 0,095 & 0,113 & 0,101 & 0,092 & 0,088 & 0,094 & 0,091 \\
\hline & Bułgaria & 0,143 & 0,190 & 0,145 & 0,112 & 0,124 & 0,109 & 0,100 & 0,131 & 0,114 & 0,122 & 0,114 & 0,101 \\
\hline & Estonia & 0,159 & 0,172 & 0,184 & 0,199 & 0,258 & 0,213 & 0,168 & 0,150 & 0,121 & 0,130 & 0,127 & 0,117 \\
\hline & Słowacja & 0,104 & 0,089 & 0,096 & 0,082 & 0,077 & 0,080 & 0,083 & 0,082 & 0,091 & 0,116 & 0,109 & 0,118 \\
\hline & Średnia* $^{*}$ & 0,112 & 0,115 & 0,108 & 0,103 & 0,111 & 0,102 & 0,096 & 0,098 & 0,095 & 0,094 & 0,089 & 0,087 \\
\hline \multirow{16}{*}{ UE15 } & Średnia* & 159 & 0,160 & 0,138 & 0,135 & 0,153 & 0,148 & 0,142 & 0,131 & 0,132 & 0,127 & 0,123 & 0,118 \\
\hline & Austria & 088 & 0,105 & 0,080 & 0,076 & 0,085 & 0,076 & 0,080 & 0,084 & 0,092 & 0,088 & 0,081 & 0,070 \\
\hline & Dania & 0,091 & 0,087 & 0,085 & 0,080 & 0,086 & 0,080 & 0,078 & 0,079 & 0,068 & 0,075 & 0,086 & 0,077 \\
\hline & Finlandia & 0,174 & 0,260 & 0,156 & 0,114 & 0,098 & 0,093 & 0,089 & 0,081 & 0,083 & 0,093 & 0,089 & 0,080 \\
\hline & Włochy & 0,084 & 0,079 & 0,082 & 0,093 & 0,102 & 0,119 & 0,102 & 0,090 & 0,087 & 0,092 & 0,084 & 0,084 \\
\hline & Hiszpania & 0,179 & 0,128 & 0,134 & 0,138 & 0,144 & 0,153 & 0,154 & 0,120 & 0,124 & 0,109 & 0,103 & 0,095 \\
\hline & Wlk. Brytania & 0,151 & 0,136 & 0,126 & 0,121 & 0,137 & 0,167 & 0,148 & 0,124 & 0,107 & 0,102 & 0,105 & 0,101 \\
\hline & Niemcy & 0,100 & 0,100 & 0,095 & 0,090 & 0,094 & 0,101 & 0,105 & 0,100 & 0,103 & 0,104 & 0,108 & 0,105 \\
\hline & Francja & 0,096 & 0,091 & 0,104 & 0,107 & 0,130 & 0,159 & 0,156 & 0,136 & 0,126 & 0,121 & 0,115 & 0,106 \\
\hline & Szwecja & 0,150 & 0,124 & 0,125 & 0,131 & 0,123 & 0,131 & 0,120 & 0,141 & 0,129 & 0,126 & 0,123 & 0,109 \\
\hline & Grecja & 0,143 & 0,150 & 0,158 & 0,135 & 0,130 & 0,134 & 0,152 & 0,136 & 0,135 & 0,123 & 0,120 & 0,128 \\
\hline & Portugalia & 0,327 & 0,298 & 0,216 & 0,178 & 0,185 & 0,193 & 0,177 & 0,155 & 0,173 & 0,146 & 0,127 & 0,129 \\
\hline & Belgia & 0,189 & 0,188 & 0,180 & 0,169 & 0,173 & 0,172 & 0,170 & 0,163 & 0,160 & 0,157 & 0,152 & 0,141 \\
\hline & Holandia & 0,135 & 0,163 & 0,135 & 0,171 & 0,189 & 0,201 & 0,177 & 0,140 & 0,148 & 0,158 & 0,148 & 0,143 \\
\hline & Luksemburg & 0,246 & 0,272 & 0,210 & 0,246 & 0,406 & 0,195 & 0,219 & 0,211 & 0,224 & 0,211 & 0,186 & 0,170 \\
\hline & Irlandia & 0,230 & 0,213 & 0,192 & 0,183 & 0,209 & 0,242 & 0,201 & 0,205 & 0,219 & 0,205 & 0,214 & 0,233 \\
\hline
\end{tabular}

* Średnia arytmetyczna wskaźników podobieństwa wszystkich krajów w danym roku.

Źródło: Eurostat, EasyComext; obliczenia własne.

Porównanie wskaźników w okresie 2004-2008 oraz 2009-2015 wykazało jednocześnie, że zakłócenia wywołane przez światowy kryzys gospodarczy - odwrotnie niż w przypadku struktur eksportu - przyspieszyły proces upodabniania 
badanych struktur importu. Warto zauważyć, że w latach przed kryzysem (20042008) wartości wybranej miary podobieństwa wzrosły w przypadku 7 krajów, w latach 2009-2015 jedynie w dwóch - na Słowacji i w Niemczech.

Powyższe tendencje wskazują, że w analizowanym okresie po akcesji wystąpił proces konwergencji importowej na rynku 25 państw członkowskich (UE-10 i UE-15). Postępujący proces ujednolicania wzorców konsumpcyjnych zharmonizował popyt na dobra importowe, którymi handlowano w ramach JRE UE-10 i UE-15. Można wnioskować, że importerzy zbudowali na tym obszarze bardziej trwałe, strategiczne relacje handlowe względem krajów trzecich.

Rysunek 5. Wskaźniki podobieństwa struktur importu

(wg odległości Euklidesa) krajów UE10 i UE15

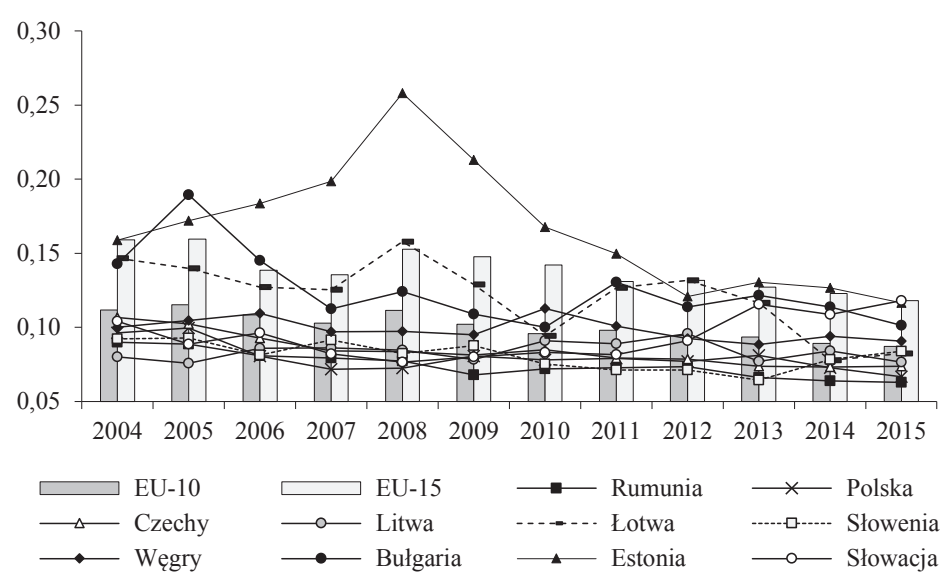

Zakresy minimalne i maksymalne oraz wartości średnie wskaźników odległości Euklidesa:
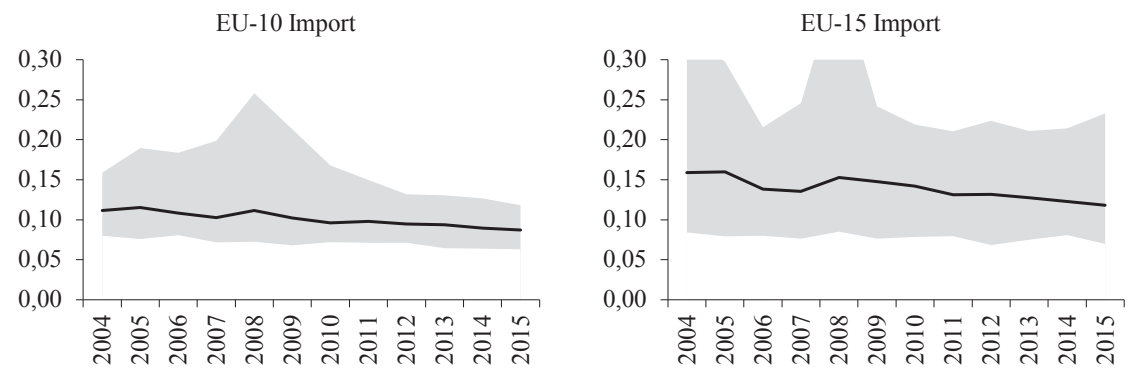

Źródło: na podstawie danych w tab. 2. 
Analiza podobieństwa struktur sprzedaży zagranicznej krajów UE-10 i UE-15 na JRE państw członkowskich w latach 2014-2015 nie wykazała wyraźnego procesu konwergencji eksportowej. Z kolei badanie podobnych tendencji w strukturze zakupów z zagranicy potwierdziło, że miał miejsce bardziej znaczący proces konwergencji importowej na rynku 25 państw członkowskich (UE-10 i UE-15). Pomimo tych niejednoznacznych wniosków wynikających ze szczegółowej analizy struktur wymiany (realizowanej na poziomie czterocyfrowych kodów nomenklatury scalonej CN4), pogłębiony dzięki rozszerzeniu w latach 2004 i 2007 proces europejskiej integracji gospodarczej oraz rozwijający się strukturalnie handel na jednolitym rynku badanych krajów Europy Zachodniej i Centralnej przyniósł wymierny efekt. W latach 2004-2015 w krajach UE-10 wystąpił oczekiwany w teorii

Rysunek 6. PKB per capita (EUR) w krajach UE-10 i UE-15 w latach 2004-2015

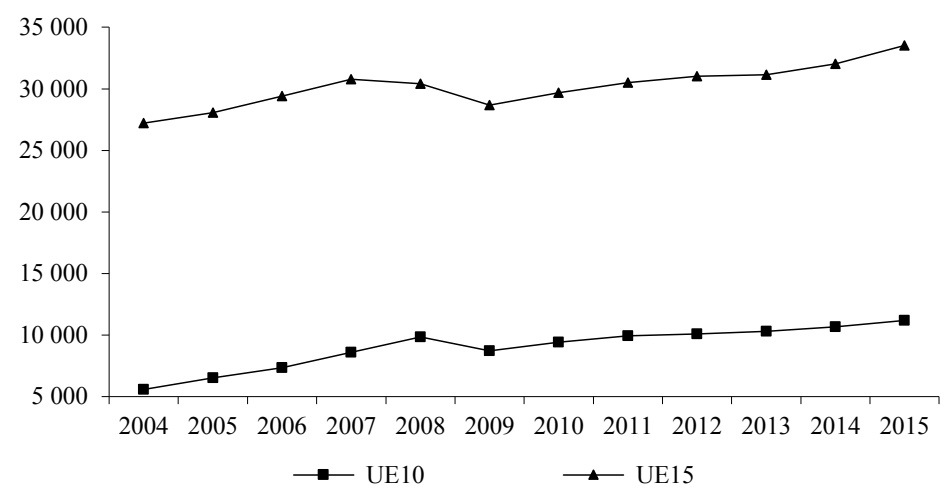

\begin{tabular}{|c|c|c|c|c|c|c|c|c|c|c|c|c|c|}
\hline $\begin{array}{l}\text { Rok/ } \\
\text { grupa }\end{array}$ & 2004 & 2005 & 2006 & 2007 & 2008 & 2009 & 2010 & 2011 & 2012 & 2013 & 2014 & 2015 & $\begin{array}{c}\text { Dynamika } \\
2015 / 2004 \\
(\%)\end{array}$ \\
\hline \multicolumn{13}{|c|}{ PKB (mld EUR) } & \\
\hline UE-10 & 570 & 665 & 747 & 871 & 992 & 877 & 946 & 995 & 1007 & 1027 & 1059 & 1111 & 195 \\
\hline UE-15 & 10476 & 10869 & 11446 & 12045 & 11989 & 11350 & 11801 & 12126 & 12371 & 12462 & 12875 & 13532 & 129 \\
\hline \multicolumn{13}{|c|}{ Liczba ludności (mln) } & \\
\hline UE-10 & 102,2 & 101,9 & 101,6 & 101,3 & 100,8 & 100,6 & 100,2 & 100,0 & 99,8 & 99,6 & 99,3 & 99,2 & 97 \\
\hline UE-15 & 384,9 & 387,3 & 389,4 & 391,5 & 394,0 & 396,0 & 397,4 & 397,4 & 398,7 & 400,0 & 402,1 & 403,8 & 105 \\
\hline \multicolumn{13}{|c|}{ PKB per capita (EUR) } & \\
\hline UE-10 & 5578 & 6526 & 7356 & 8593 & 9842 & 8718 & 9435 & 9953 & 10098 & 10314 & 10660 & 11201 & 201 \\
\hline UE-15 & 27215 & 28065 & 29395 & 30768 & 30429 & 28664 & 29696 & 30512 & 31024 & 31153 & 32018 & 33511 & 123 \\
\hline
\end{tabular}


konwergencji efekt doganiania. Hipoteza, że w krajach biedniejszych dochody na mieszkańca - mierzone m.in. wskaźnikiem PKB per capita - rosną szybciej niż w krajach bogatych, znalazła swoje potwierdzenie empiryczne. W badanym okresie średni dochód na mieszkańca wzrósł w krajach UE-10 aż dwukrotnie - z poziomu 5,6 do 11,2 tys. EUR. W tym samym czasie społeczeństwa krajów UE-15 nadal bogaciły się zwiększając swoje dochody o $23 \%$ z poziomu 27,2 do 33,5 tys. EUR. W rezultacie, w długiej perspektywie, wszystkie społeczeństwa na badanym obszarze JRE powinny żyć na podobnym, wysokim poziomie. Jednocześnie, przy zachowaniu dotychczasowych tendencji, wzrost dobrobytu jednej grupy państw (UE-10) nie powinien odbywać się kosztem drugiej (UE-15).

\section{Podsumowanie}

Proces upodabniania się struktur wymiany handlowej krajów UE-10 z krajami UE-15 do analogicznych struktur w wymianie wzajemnej potwierdza, iż w badanych latach po akcesji (2004-2015) obszary krajów UE-10 i UE-15 traktowane były przez importerów i eksporterów z krajów UE-10 w coraz większym zakresie jako jednolity rynek. Przy tym znaczna część podmiotów gospodarczych z krajów piętnastki zaangażowanych w wymianę handlową na tym obszarze także traktowała obszar działalności biznesowej w granicach państw UE-15 i UE-10 jako jednolity. Wzmocniło to proces konwergencji oraz pogłębione efekty dobrobytowe, co było jedną z podstawowych przesłanek realizowanego procesu europejskiej integracji gospodarczej.

Tendencje te były konsekwencją ujednolicania się wzorców zakupowych wśród konsumentów oraz popytu inwestycyjnego w ramach przedsiębiorstw działających na obszarze analizowanych krajów członkowskich. Z punktu widzenia podaży, były one efektem m.in. realizowania strategii synergii i realizacji efektów skali w ramach bardziej ujednoliconej oferty handlowej firm eksportujących na rynku krajów unijnych. Nie bez znaczenia były także decyzje inwestorów (zagranicznych i krajowych), którzy, wykorzystując decyzje o liberalizacji handlu, zarówno w ramach UE-10, jak i pomiędzy krajami UE-10 i UE-15, w coraz szerszym zakresie podejmowali decyzje o alokacji produkcji na całym zintegrowanym obszarze. Skutkowało to nasileniem się efektu kreacji i przesunięcia strumieni handlu oraz upodabniania się ich struktur w obydwu relacjach. 


\section{Literatura}

Benedictis, De. L., Tajoli, L. (2003). Economic Integration, Similarity and Convergence in the EU and CEECs Trade Structures. Flowenla Discussion Paper 4. Hamburgisches Welt-Wirtschafts-Archiv (HWWA), Hamburg Institute of International Economics.

Czubek, H., Molendowski, E. (2005). Zbliżanie struktur wymiany handlowej krajów CEFTA z krajami UE w okresie przygotowań do członkostwa. Wspólnoty Europejskie, 11 .

Eurostat. EasyComext. Pobrano z: http://epp.eurostat.ec.europa.eu/newxtweb (17.03.2017).

Gierczycka-Bednarek, A. (2015). Konwergencja czy dywergencja we współczesnej gospodarce światowej. W: D. Kopycińska (red.), Działania ekonomiczne podmiotów rynkowych. Materiały konferencyjne. Szczecin: Katedra Mikroekonomii Uniwersytetu Szczecińskiego.

Głodowska, A. (2016). Struktura specjalizacji eksportowej a proces konwergencji państw Unii Europejskiej. Finanse, Rynki Finansowe, Ubezpieczenia, 3 (81).

Kopeć, U. (1995). Zasady liberalizacji handlu wyrobami przemysłowymi w umowach handlowych Polski. W: E. Kawecka-Wyrzykowska (red.), Umowy o wolnym handlu ze Wspólnotami Europejskimi oraz krajami EFTA i CEFTA i uzgodnienia Rundy Urugwajskiej. Skutki dla polskiego handlu zagranicznego. Warszawa: IKCHZ.

Ministerstwo Finansów (2016). Monitor Konwergencji z Uniq Gospodarcza i Walutowa. Warszawa, marzec.

Molendowski, E. (2007). Liberalizacja wymiany handlowej krajów Europy Środkowowschodniej w okresie transformacji. Ze szczególnym uwzględnieniem doświadczeń krajów CEFTA. Kraków: Wydawnictwo Uniwersytetu Ekonomicznego w Krakowie.

Molendowski, E. (2003). Państwa Europy Środkowo-Wschodniej wobec wyzwań rozwojowych. W: S. Miklaszewski i in. (red.), Międzynarodowe stosunki gospodarcze u progu XXI wieku. Warszawa: Difin.

Molendowski, E., Polan, W. (2009). Handel wewnątrzgałęziowy nowych państw - przed i po akcesji. Wspólnoty Europejskie, 4 (197).

Molendowski, E., Polan, W. (2013). Changes in the Foreign Trade Structure of the New Member States (EU-10) during the Years 1999-2011 - A Convergence to Requirements of the Single European Market. W: Trends in the World Economy. Key Problems of Selected Economies, Regions and Industries. Szczecin: Wydawnictwo Naukowe Uniwersytetu Szczecińskiego.

Polan, W. (2010). Zmiany podobieństwa struktur handlu zagranicznego nowych krajów członkowskich Unii Europejskiej przed i po akcesji. W: J. Misala (red.), Teoria i polityka wzrostu gospodarczego - osiagnięcia i doświadczenia. Warszawa: CeDeWu. 
Polan, W. (2015). Główne tendencje w handlu zagranicznym nowych państw członkowskich (UE-10) po akcesji do Unii Europejskiej. Zeszyty Naukowe Uniwersyetu Ekonomicznego w Krakowie, 10 (946).

\title{
CHANGES IN THE FOREIGN TRADE STRUCTURE OF THE NEW MEMBER STATES (EU-10) BETWEEN 2004-2015 - AN ONGOING CONVERGENCE ON THE SINGLE EUROPEAN MARKET
}

\begin{abstract}
This analysis is an attempt to clarify whether foreign trade structural changes in consecutive years between 2004-2015 prove the execution of - expected in theory - convergence process on the Single European Market (SEM) and moreover, if - after 2004 and 2007 EU enlargements - the markets of the EU-10 and EU-15 countries are treated by the importers and exporters, from the EU-15 and EU-10, increasingly as a single market. The results and conclusions confirm the trend of increasing similarities in the analyzed trade structures of the Member States (EU-10 and EU-15) in their corresponding structures of trade between European partners. Especially importers contribute significantly to this trade convergence by building up stable, strategic trade relations, that in relation to third parties constitute much stronger single European market.
\end{abstract}

Keywords: convergence, single European market, foreign trade

JEL codes: F14, F15 